\title{
Product Relationship Identifier
}

National Cancer Institute

\section{Source}

National Cancer Institute. Product Relationship Identifier. NCI Thesaurus. Code C95384.

A unique symbol that establishes the identity of the relationship between two or more

products. 